Regulating Technological Innovation 
This page intentionally left blank 


\section{Regulating Technological Innovation}

\section{A Multidisciplinary Approach}

Edited by

Michiel A. Heldeweg

Professor of Public Governance Law, University of Twente, the Netherlands and

Evisa Kica

Researcher in Governance and Innovation, University of Twente, the Netherlands

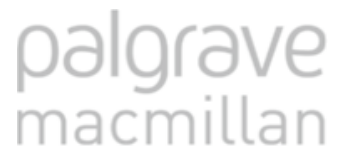




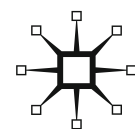

(C) Michiel A. Heldeweg and Evisa Kica 2011

Softcover reprint of the hardcover 1st edition 2011 978-0-230-36363-2

All rights reserved. No reproduction, copy or transmission of this publication may be made without written permission.

No portion of this publication may be reproduced, copied or transmitted save with written permission or in accordance with the provisions of the Copyright, Designs and Patents Act 1988, or under the terms of any licence permitting limited copying issued by the Copyright Licensing Agency, Saffron House, 6-10 Kirby Street, London EC1N 8TS.

Any person who does any unauthorized act in relation to this publication may be liable to criminal prosecution and civil claims for damages.

The authors have asserted their rights to be identified as the authors of this work in accordance with the Copyright, Designs and Patents Act 1988.

First published 2011 by

PALGRAVE MACMILLAN

Palgrave Macmillan in the UK is an imprint of Macmillan Publishers Limited, registered in England, company number 785998, of Houndmills, Basingstoke, Hampshire RG21 6XS.

Palgrave Macmillan in the US is a division of St Martin's Press LLC, 175 Fifth Avenue, New York, NY 10010.

Palgrave Macmillan is the global academic imprint of the above companies and has companies and representatives throughout the world.

Palgrave ${ }^{\circledR}$ and Macmillan ${ }^{\circledR}$ are registered trademarks in the United States, the United Kingdom, Europe and other countries.

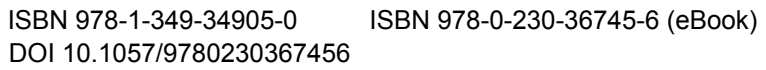

This book is printed on paper suitable for recycling and made from fully managed and sustained forest sources. Logging, pulping and manufacturing processes are expected to conform to the environmental regulations of the country of origin.

A catalogue record for this book is available from the British Library.

A catalog record for this book is available from the Library of Congress.

$\begin{array}{rrrrrrrrrr}10 & 9 & 8 & 7 & 6 & 5 & 4 & 3 & 2 & 1 \\ 20 & 19 & 18 & 17 & 16 & 15 & 14 & 13 & 12 & 11\end{array}$




\section{Contents}

List of Tables vii

Notes on Contributors viii

Introduction $\quad 1$

Michiel A. Heldeweg and Evisa Kica

Part I General Analysis of the Regulation and Technological Innovation Relationship

1 Regulation for Innovation: A Comparative Inquiry into a Regulatory Pair of Twins

Antoni J. P. Brack

2 Regulation, Innovation and Competitiveness

Shawn Donnelly

3 Legal Design of Smart Rules and Regimes: Regulating Innovation

Michiel A. Heldeweg

4 Regulating Technological Innovation through

Informal International Law: The Exercise of

International Public Authority by Transnational Actors

Ramses A. Wessel

Part II Specific Exemplary Areas and Connected Issues of Regulating Technological Innovation

5 The Unlikely Emergence of Next Generation Networks in the Light of Prevailing Telecom Regulation

Lesley C. P. Broos

6 Deutsche Telekom and Pacific Bell v. LinkLine: Does

Competition Law have a Place in Regulated Industries?

Martin W. Holterman

7 Is Europe Turning into a 'Technological Fortress'?

Innovation and Technology for the Management of

EU's External Borders: Reflections on FRONTEX and

EUROSUR

Luisa Marin 
8 Regulating Public-Private Modalities of Legitimate Innovation: An Ex Ante Analysis Framework

Maurits P. T. Sanders

Part III Emerging Technologies and Technology

Innovation: Regulatory Issues, Actors and Patents

9 Transnational Regulation of Nanotechnology: Institutional Diversity in Agenda Setting and State Support

Nupur Chowdhury

10 The European Patent System: Emerging Technologies, the Patent Quality Challenge and Mechanisms to

Deal with it

190

Evisa Kica

11 Regulatory and Policy Impact on the Use of

Existing Patents to Enhance Technological Innovation

in the Single Market of the European Union

Victor Rodriguez

Conclusion

Michiel A. Heldeweg and Evisa Kica

Index 


\section{List of Tables}

3.1 Regulatory channelling of innovation 55

3.2 Dynamics (effective and efficient) 60

5.1 Attractiveness of new entrant strategies in an $\begin{array}{ll}\text { unregulated market } & 104\end{array}$

5.2 Institutional influence of cost-based mandated access 105

5.3 Institutional influence of several common $\begin{array}{ll}\text { regulatory measures } & 107\end{array}$

8.1 The three dimensions of legitimacy 157

8.2 Underlying value orientations of forms of coordination 161

8.3 Forms of failure 162

8.4 Forms of PPP 163

8.5 Summary of legal forms 164 


\section{Notes on Contributors}

Antoni J. P. Brack is Professor of Business Legal Studies at the University of Twente, the Netherlands. He has authored a book on managerial law (Bedrijfsrecht, 5th edn, 2010) and published numerous articles including in the European Business Law Journal. He is founder and co-editor of the Dutch Consumer Law Journal. He is a non-executive director of a UK-owned Dutch chemical company and a part-time judge in the Court of Appeal at Arnhem, the Netherlands.

Lesley C. P. Broos is a researcher and lecturer in the combined field of IT/telecommunications and law at the University of Twente, the Netherlands. He is currently preparing a PhD thesis on enhancing technological innovation in telecommunication infrastructure services and has published on the issues of regulatory supervision and first and second mover advantage theory relating to technology advancement.

Nupur Chowdhury is a PhD student in law at the School of Management and Governance, University of Twente. She is researching the issue of legal certainty in the context of a multilevel product quality and safety regulation of medical products.

Shawn Donnelly is an assistant professor of European Economic Governance at the University of Twente, the Netherlands. He is the author of Reshaping Economic and Monetary Union (Manchester 2004) and The Regimes of European Integration: Constructing Governance of the Single Market (Oxford 2010).

Michiel A. Heldeweg is Professor of Public Governance Law at the University of Twente and an honorary judge (within the Dutch District Court system; administrative bench). His research is on 'smart rules and regimes', fostering technological innovation while protecting against related risks, as set out in his 2009 inaugural lecture. His focus lies on regulation in the field of Environmental and Energy Law ('Sustainable Energy Law'). He is especially interested in matters of legal design and good legal governance in the new or post-regulatory state.

Martin W. Holterman is a post-doctoral researcher at the European University Institute. Previously, he was a PhD student at the University of Twente, the Netherlands. His research includes a theoretical analysis 
of the problems of semi-public institutions applying neo-institutional economics, and when such a set up is optimal.

Evisa Kica is a PhD student at the University of Twente. Her research focuses on the legitimacy of the multilevel standardisation process as it relates to the field of nanotechnology. In addition, she has been involved in EU contract research projects related to patent quality and innovation issues, and has investigated the role of patents in emerging technologies.

Luisa Marin is an assistant professor of European Law at the University of Twente, the Netherlands. Her research focuses on the constitutional analysis of the policies and instruments of the EU's Area of Freedom, Security and Justice, with particular attention to European criminal law cooperation. She has written on the European Arrest Warrant and its implementation in domestic legal Orders and co-edited the book Still not resolved? Constitutional Challenges to the European Arrest Warrant, Nijmegen, Wolf Legal Publishers, 2009, together with Elspeth Guild. Her recent research covers migration and border controls and Internet law.

Victor Rodriguez is an assistant professor in the Department of Legal and Economic Governance Studies at the University of Twente. He lectures on European Economic Governance and Macroeconomics. He has extensively researched the effects of biological material transfer agreements and has been involved in European projects on patents, corporate $R \& D$ and innovation. Previously, he was a tenured researcher in the TNO Innovation Policy Group and a visiting scholar at the University of Ottawa and the Conference Board of Canada.

Maurits P. T. Sanders studied public administration at the University of Twente in the Netherlands. He is a PhD student at the University of Twente while working as a lecturer in Public Policy Making at Saxion Universities of Applied Sciences in the Netherlands. His PhD research is on complex decision making in public-private partnerships.

Ramses A. Wessel is Professor of the Law of the European Union and other International Organisations at the University of Twente, the Netherlands. His research focuses on the relationship between international, EU and national laws. He is the editor of the International Organizations Law Review and in 2008 co-edited the book Multilevel Regulation and the EU: The Interplay between Global, European and National Normative Processes (The Hague/Boston: Martinus Nijhoff Publishers). 